Send your letters to the Editor, British Dental

Journal, 64 Wimpole Street, London W1G 8YS

E-mail bdj@bda-dentistry.org.uk

Priority will be given to letters less than 500

words long. Authors must sign the letter,

which may be edited for reasons of space.

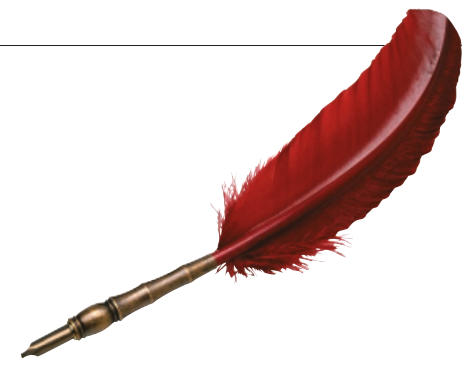

designed in such a way as to minimise the reduction in $p H$. The $\mathrm{pH}$ of the filtered water is dependent upon the composition of the influent water but in the vast majority of cases the $\mathrm{pH}$ will not drop below 5.5, which is within the range of the Drinking Water Regulations ${ }^{1}$. In recent independent tests using different types of tap water, over 99\% of the measurements gave a $\mathrm{pH}$ of above 5.5 .

A Brita cartridge is designed to last for 4 weeks or around 150 litres. The $\mathrm{pH}$ of the water will increase throughout the life of the cartridge with the majority of the water filtered through the cartridge having a $\mathrm{pH}$ of between 6.5 and 8.

1. The Water Supply (Water Quality) Regulations 1989. Norwich:HMSO

\section{A century of dentistry}

Sir,- I recently accessed the Public Records Office website www.pro.gov.uk to see the 1901 Census.

I found that my grandfather W H Bryant was an apprentice dentist in Camberwell at the time, so an unbroken 100 years of dentistry has been carried out by the family. Total man-years worked by my grandfather, father, uncle and myself are over 150 years. A. M. Bryant

Le Busseau

France

\section{Toothache from composite filling}

Sir,- About one month ago, I noticed a missing buccal filling in my own tooth, a lower left 4, giving mild symptoms of occasional pain. A colleague inserted a composite filling using 37\% phosphoric acid and Scotchbond in this shallow cavity with minimal preparation. Almost immediately I felt shooting pains throughout the mandible extending, over the next few days, to infraorbital pain on the left hand side lasting most of the day and night. On removal of the filling after four days and its replacement by Ledermix and Cavit, the pain eased within minutes. Had this episode happened on anyone but myself, I would have been inclined to question the patient's truthfulness. However, I recalled a similar incident happened to me some 15 years ago.

Is it possible that I have developed a hypersensitive reaction to composite fillings? Nothing similar has happened to me with amalgam or glass ionomer restorations. I would welcome any comments from colleagues.

\section{B. Arends}

Hitchin

\section{Prolonged paraesthesia}

Sir,- I read with interest recently a letter to the editor of the Journal of Oral \& Maxillofacial Surgery ${ }^{1}$ on the apparent relationship between inferior alveolar nerve block injections with articaine and an apparently increased incidence of prolonged dysaesthesia. At the Leeds Dental Institute we too have observed an apparent increase in the incidence of prolonged dysaesthesia following inferior alveolar nerve block injection in the last few years (917 cases), all but one of which have been associated with articaine administration.

Your readers may wish to refer to a paper by D A Haas and D Lennon ${ }^{2}$ which showed a dramatic rise in reported incidents of dysaesthesia following local anaesthetic administration in Ontario, coincident with the introduction of articaine to dental practice in that province.

It would seem that there is sufficient evidence to urge some caution in the widespread use of articaine as a local anaesthetic alternative to lignocaine. A widespread survey of the relationship of prolonged dysaesthesia to particular drug choices would seem justified to clarify this apparent adverse effect.

\section{J. Pedlar}

Leeds

1. van Eden S P, Patel M F. Prolonged Paraesthesia Following Inferior Alveolar Nerve Block Using Articaine. Br J Oral Maxillofac Surg 2002; 40: 519-520 2. Haas D A, Lennon D. A 21 Year Retrospective Study of Reports of Paraesthesia Following Local Anaesthetic Administration. J Can Dent Assoc 1995; 61: 319-330
The filtration process can have an effect on the $\mathrm{pH}$ of the water but the cartridges are 